\title{
Nova družina: prehod mladostnika iz primarne družine v izvendružinsko institucionalno obravnavo
}

\author{
Mateja Marovič \\ Univerza na Primorskem \\ mateja.marovic@pef.upr.si
}

\begin{abstract}
Prispevek obravnava pogled mladostnikov in vzgojiteljev na prehodu iz primarne družine $v$ izvendružinsko institucionalno obravnavo, pri čemer upošteva dve različni perspektivi - perspektivo mladostnikov in njihovih vzgojiteljev. Kvalitativna raziskava, $v$ katero je bilo vključenih sedem udeležencev (trije mladostniki in štirje vzgojitelji) z izkušnjo prehoda, se osredotoča predvsem na fazo prehoda in fazo sprejema/namestitve. Rezultati raziskave kažejo, da je doživljanje prehoda iz primarne družine v izvendružinsko institucionalno obravnavo - tako pri mladostnikih kot njihovih vzgojiteljih - povezano s kompleksno, večdimenzionalno ter hkrati zelo subtilno dinamiko namestitvenega postopka, ki se ga ne da razumeti enoznačno.

Ključne besede: prehod, nameščanje, izvendružinska institucionalna obravnava, mladostniki s čustvenimi in vedenjskimi težavami in/ali motnjami, socialnopedagoška obravnava
\end{abstract}

\section{Uvod}

Prehod mladostnika iz primarne družine $v$ izvendružinsko institucionalno obravnavo predstavlja poseg $v$ družino, ki običajno povzroči številne čustveno negativne reakcije (Marovič 2019) pri vseh deležnikih, ki so z ukrepom oddaje ${ }^{1}$ neposredno povezani - pri starših občutek krivde zaradi lastne vzgojne neuspešnosti, pri mladostniku pa jezo, sram, strah pred neznanim ter občutke nemoči (Strokovni svet Republike Slovenija za strokovno izobraževanje 2004). Vzroke, ki najpogosteje botrujejo oddaji posameznika $v$ izvendružinsko institucionalno obravnavo, ${ }^{2}$ lahko strnemo $v$ naslednjih šest

\footnotetext{
${ }^{1}$ Oddaja otroka/mladostnika v izvendružinsko institucionalno obravnavo v Sloveniji temelji na naslednjih zakonskih osnovah: Družinski zakonik (2017), Kazenski zakonik (2012) in Zakon o nepravdnem postopku (2019).

${ }^{2} \mathrm{~S}$ terminom izvendružinska institucionalna obravnava $v$ pričujočem prispevku zajamemo vse vzgojne zavode, stanovanjske skupine in mladinske domove, ki v Sloveniji izvajajo vzgojo in izobraževanje otrok/mladostnikov s čustvenimi in vedenjskimi težavami in/ali motnjami. Kljub razlikam med naštetimi institucijami (npr. v starosti in težavnosti populacije, spolu, organizira-
} 
sklopov (Marovič 2019, 131; prim. Rapuš Pavel in Kobolt 2008; Krajnčan 2006 idr.):

- neugodno družinsko ozadje (ločitve, bolezni, smrt, zanemarjenost; preobremenjenost, nemoč, psihične težave staršev; različne vrste zasvojenosti; konfliktnost staršev/partnerjev; nasilje, spolne in druge zlorabe ipd.) v povezavi s socialno-ekonomsko-družbeno deprivilegiranostjo (brezposelnost, nizek socialni status, neprimerni bivalni prostori, nezmožnost nudenja osnovnih življenjskih pogojev/dobrin, neizobraženost/nizka izobraženost) ter odsotnostjo različnih vrst kapitala (ekonomskega, socialnega, kulturnega);

- težave v šoli (odklanjanje šole in učnega dela, izostajanje od pouka, verbalno/fizično nasilje nad sošolci in/ali strokovnimi delavci, neupoštevanje šolskih pravil ipd.);

- neugoden vpliv okolja (primarnega/sekundarnega);

- pripadnost odklonskim vrstniškim skupinam (negativni vplivi vrstnikov, vandalizem);

- prisotnost oz. konzumiranje različnih nedovoljenih substanc (alkohol, trde/mehke droge) ter

- koeksistenca naštetih dejavnikov (medsebojno učinkovanje bioloških, psiholoških, socialno-ekonomskih, okoljskih ter drugih dejavnikov).

Sodobna doktrina nameščanja $v$ tovrstne ustanove $v$ Sloveniji je danes (pravnoformalno) zajeta $v$ samem izhodišču vzgojne pomoči. Upošteva inovativne socialnopedagoške koncepte zavodske vzgoje, ki izhajajo iz načel deinstitucionalizacije (Krajnčan 2019; Kobolt, Žižak in Zrim Martinjak 2019), normalizacije (Krajnčan 2012), participacije (Marovič 2017), v življenjski svet usmerjene socialnopedagoške pomoči (Grunwald in Thiersch 2008) ipd. Hkrati ustanovitev strokovnih centrov ter sprejetje novega Zakona o obravnavi otrok in mladostnikov s čustvenimi in vedenjskimi težavami in motnjami

nosti izobraževanja in življenja v posamezni ustanovi ipd.) imajo vse tovrstne institucije skupen temelj v namenu svojega delovanja (Martinjak 2017). Skupni so varstvo, nega, oskrba ter skrb za vzgojo in izobraževanje otrok/mladostnikov s čustvenimi in vedenjskimi težavami in/ali motnjami. Skupni so cilji vzgojnega programa - s poudarkom na temeljnem (ponovna in uspešna vključitev otroka/mladostnika v običajno sredino) -, načela kot tudi namen zavodske vzgoje, ki v vseh vzgojno-izobraževalnih ustanovah temelji na zagotovitvi varnega, zdravega osebnostnega razvoja s kompenzacijo razvojnih primanjkljajev in vrzeli na kognitivnem, čustvenem ter socialnem področju (prim. Ministrstvo za izobraževanje, znanost in šport b. I.). Prav tako vse naštete institucije veljajo za posredno obliko socialne integracije, saj so otroci/mladostniki izločeni iz domačega okolja (družine, prijateljev, šole), socialno (re)integracijo pa jim omogočamo s posebnimi strokovnimi (socialnopedagoškimi idr.) metodami (Krajnčan 2012; prim. Skalar 1998). 
v vzgoji in izobraževanju (2020) v slovenski zavodski prostor vnaša (tudi z vidika prehodov) nedvomno več kot potrebne spremembe ${ }^{3} v$ polju obravnave posameznikov $s$ čustvenimi in vedenjskimi težavami in/ali motnjami (ČVT/M).

Rosenthal (2017 v Kobolt, Žižak in Zrim Martinjak 2019) ugotavlja, da na svetu več kot deset milijonov otrok živi in odrašča v različnih ustanovah. Organizacija EUROCHILD (2019 v Kobolt, Žižak in Zrim Martinjak 2019) ocenjuje, da je $v$ Evropi okoli leta 2000 okrog 150.000 mladih živelo $v$ eni od bivalnih/rezidenčnih oblik, podatki Encyclopedia of Social Work (National Association of Social Workers in Oxford University Press 2013 v Kobolt, Žižak in Zrim Martinjak 2019) pa kažejo, da se je število mest v različnih oblikah ustanov za mlade v ZDA v 28 letih (od leta 1970 pa do leta 1998) za šestkrat povečalo. Če navedeno povežemo z zgoraj že izpostavljenimi različnimi dejavniki tveganja, ki pri posameznikih s ČVT/M, ${ }^{4}$ nameščenih v izvendružinskih institucionalnih ustanovah, še dodatno stopnjujejo poglabljanje njihove neugodne življenjske situacije, velja poudariti, da mora ukrep oddaje predstavljati zadnjega izmed korakov intervencij, ko je separacija posameznika od družine (zaradi različnih razlogov) nujna in so predhodno, v primarnem okolju, izčrpani že vsi alternativni arzenali pomoči. Prav tako je treba pri prehodu še posebej upoštevati (pre)pogosto zanemarjen vidik doživljanja mladostnikov, ki se jih usmerja v zavodsko institucijo. Le-ta se odraža v neizogibni spremembi življenjskih okoliščin, ločenosti od družine ipd. in lahko dodatno ogroža njegovo psihosocialno funkcioniranje.

\section{Problem, namen, cilji in raziskovalna vprašanja}

Izhajajoč iz doktrine in aktualne prakse nameščanja $v$ izvendružinskih institucionalnih ustanovah $v$ Sloveniji (kot tudi umanjkanja raziskav na tem področju ${ }^{5}$ ) je mogoče sklepati, da se samemu prehodu, namestitvi ter pr-

\footnotetext{
${ }^{3}$ Vendar pa so se kljub kratkemu času njegove veljave na nekaterih področjih že pokazale diskrepance (katerih obravnava žal presega okvirje pričujoče raziskave) in jih bo treba v prihodnosti še prevetriti.

${ }^{4}$ Za ČVT/M, očitne pri posameznikih nameščenih v VZ, je značilno, da so izražene v različnih stopnjah, katerih narava je zelo kompleksna (Inštitut Republike Slovenije za socialno varstvo 2011) Zato je treba pri njihovi opredelitvi upoštevati medsebojno učinkovanje bioloških, psiholoških, socialnih in okoljskih dejavnikov (prim. Kriteriji za opredelitev vrste in stopnje primanjkljajev, ovir oz. motenj otrok s posebnimi potrebami (Zavod Republike Slovenije za šolstvo 2015)).

${ }^{5}$ „Odsotnost raziskovalnega zanimanja za področje dela vzgojnih zavodov zagotovo pomeni tudi nepoznavanje tega, kar se $v$ teh ustanovah dogaja, tako na ravni otrok in mladostnikov kot na ravni zaposlenih« (Martinjak 2017, 90). V slovenskem prostoru raziskav - razen maloštevilnih diplomskih in magistrskih nalog -, ki bi izhajale iz doživljanja mladostnikov in njiho-
} 
vemu dnevu v instituciji - predvsem z vidika doživljanja mladostnikov (posredno tudi vzgojiteljev) - posveča premalo pozornosti. Vsa prizadevanja, ${ }^{6}$ ki izhajajo iz čimprejšnje in čim uspešnejše vključitve posameznika v institucijo, so namreč (pre)pogosto povezana s takojšnjo vključitvijo v šolski sistem oz. šolanje posameznika, vzgojno-izobraževalni proces ustanove, poznavanje dnevnega/hišnega reda ipd., premalo pozornosti pa se namenja njegovemu doživljanju prehoda in percepciji prvega dne. Pozabljamo namreč, da so mladostniku z »novo (zakonsko določeno) družino« na nek način dodeljeni tudi »novi« bratje in sestre, »nove« mame in očetje, »novi« prijatelji in še kdo, ki si jih ni izbral prostovoljno, temveč so mu bili z ukrepom oddaje v vzgojni zavod (VZ), stanovanjsko skupino (SS) ali mladinski dom (MD) določeni od zunaj. Vse te na novo definirane in pravnoformalno določene okoliščine od posameznika zahtevajo dobršno mero rekonstruiranja njegovega dosedanjega življenjskega miljeja, za kar pa je potreben čas. Zatorej proces prehoda, ki se prekriva $z$ doživljanjem namestitve ter s prvim dnem $v$ ustanovi, vsekakor predstavlja enega izmed ključnih in odločilnih dejavnikov, ki pomembno sovpada ne samo z nadaljnjo uspešnostjo socialnopedagoške obravnave $v$ tovrstnih ustanovah, temveč tudi s temeljnim ciljem zavodske vzgoje - uspešno (re)integracijo v primarno življenjsko sredino (Nowacki 2014; Marovič 2017; Wolff in Hartig 2013).

Izhajajoč iz navedenega je namen raziskave raziskati doživljanje mladostnikov in njihovih vzgojiteljev ob prehodu posameznika iz primarne družine $v$ izvendružinsko institucionalno ustanovo/obravnavo. Znotraj tega so nas zanimala različna področja, povezana $z$ doživljanjem prehoda, s prostovoljnostjo namestitve, (pred)pripravami na sprejem/namestitev, soočanjem z novo situacijo ipd.

Cilji, ki smo jim v raziskavi sledili, so: (1) preveriti načine in postopke prehoda iz primarne družine $v$ izvendružinsko institucionalno ustanovo/obravnavo in raziskati doživljanje mladostnika/vzgojitelja v fazi prehoda; (2) ugotoviti, kakšna so pričakovanja, želje in morebitni strahovi, s katerimi se ob prehodu soočajo mladostniki/vzgojitelji; (3) z vidika mladostnikov/vzgojiteljev raziskati doživljanje prvega dne ter fazo sprejema/namestitve. Izhajajoč iz opredelitve problema in ciljev raziskave smo si zastavili naslednja raziskovalna vprašanja: (1) na kakšen način je potekal prehod mladostnika iz pri-

vih vzgojiteljev ob prehodu posameznika iz primarne družine v izvendružinsko institucionalno ustanovo/obravnavo, nismo zasledili.

${ }^{6}$ Pri zgornjih navedbah izhajamo iz izkušenj večletnega dela v eni izmed tovrstnih ustanov v Sloveniji. 
Preglednica 1 Predstavitev vzorca vzgojiteljev in mladostnikov

\begin{tabular}{|c|c|c|c|c|}
\hline & $V_{1}$ & $V_{2}$ & $V_{3}$ & $V_{4}$ \\
\hline Starost & 38 let & 42 let & 48 let & 38 let \\
\hline \multirow{2}{*}{$\begin{array}{l}\text { Skupna delovna doba v } \\
\text { tovrstnih ustanovah }\end{array}$} & 13,5 let & 2,5 let & 17 let & 13,5 let \\
\hline & $M_{1}$ & & $\mathrm{M} 2$ & $M_{3}$ \\
\hline Starost & 16 let & & 18 let & 17 let \\
\hline $\begin{array}{l}\text { Številčnosti in dolžina bivanja } \\
\text { v posamezni tovrstni ustanovi }\end{array}$ & $\begin{array}{l}\text { MD ( } 3 \text { leta } \\
\text { in } 2 \text { meseca), } \\
\text { SS ( } 5 \text { mesecev) }\end{array}$ & & $\begin{array}{l}\text { MD (3 leta } \\
\text { n } 4 \text { mesece), } \\
\text { SS (1 leto) }\end{array}$ & $\begin{array}{l}\text { VZ ( } 1 \text { leto } \\
\text { in } 3 \text { mesece), } \\
\text { SS ( } 6 \text { mesecev) }\end{array}$ \\
\hline
\end{tabular}

marne družine v izvendružinsko institucionalno ustanovo/obravnavo; (2) kateri so morebitni strahovi, želje, pričakovanja, s katerimi se ob prehodu soočajo mladostniki/vzgojitelji; (3) kako mladostniki/vzgojitelji doživljajo prvi dan v novi ustanovi ter kako doživljajo fazo sprejema/namestitve?

\section{Metodologija}

$\checkmark$ kvalitativno raziskavo je bilo vključenih sedem anketirancev ${ }^{7}$ iz dotične SS v Sloveniji, in sicer trije mladostniki (M) in štirje vzgojitelji (V), kar predstavlja vse posameznike, ki so v letu 2020/2021 (natančneje do konca meseca marca) bivali in delovali v izbrani SS. Podatki o udeležencih, relevantni za raziskavo, pri katerih izhajamo iz dokumentacije, zbrane $v$ osebnih mapah mladostnikov, ter podatkov, pridobljenih iz intervjujev, so prikazani v preglednici 1. Iz te je razvidno, da so imeli vsi mladostniki z bivanjem $v$ izvendružinskih institucijah predhodno že izkušnje, prav tako imajo vsi razen enega vzgojitelja dolgoletne delovne izkušnje $v$ tovrstnih ustanovah.

Uporabili smo deskriptivno metodo empiričnega znanstvenega raziskovanja. Podatki so bili pridobljeni s tehniko polstrukturiranega intervjuja, sestavljenega za potrebe pričujoče raziskave. Pred intervjujem je bil opravljen pogovor $z$ vodstvom, vzgojitelji ter mladostniki omenjene ustanove, $v$ katerem smo anketirance seznanili z namenom, s cilji in potekom raziskave. Vsi udeleženci so po povabilu k raziskavi v le-tej sodelovali prostovoljno. Anonimnost in zaupnost sta bili zagotovljeni. Vse intervjuje smo izvedli individualno, neposredno v SS. Pridobljene podatke smo obdelali po postopkih kvalitativne analize.

${ }^{7}$ Izhajajoč iz zagotavljanja anonimnosti in varovanja osebnih podatkov v nadaljevanju, ne glede na spolno identiteto posameznika, uporabljamo samo moško obliko poimenovanja - mladostnik in vzgojitelj. 
Preglednica 2 Rezultati kvalitativne analize - ključni pojmi in kategorije

\begin{tabular}{ll}
\hline Identificirani pojmi & Ključne kategorije \\
\hline Prostovoljnost namestitve & Faza prehoda \\
Ogled institucije & \\
Strahovi, pričakovanja, želje & \\
\hline (Pred)priprava na sprejem & Faza sprejema/namestitve \\
Sprejem - prvi dan v instituciji & \\
\hline
\end{tabular}

\section{Rezultati in interpretacija}

Po izpeljavi kvalitativne analize opravljenih intervjujev smo pojme razvrstili $v$ naslednji dve kategoriji: faza prehoda je vsebovala tri pojme, in sicer prostovoljnost namestitve, ogled institucije ter morebitne strahove, pričakovanja in želje, s katerimi se $v$ fazi prehoda srečujejo mladostniki/vzgojitelj, faza sprejema/namestitve, ki prav tako z vidika mladostnikov/vzgojiteljev vključuje (pred)pripravo na sprejem ter sam sprejem in prvi dan v instituciji, pa dva pojma. Vseh pet pojmov so prepoznali tako mladostniki kot vzgojitelji.

$\checkmark$ preglednici 2 predstavljamo pojme in ključne kategorije, ki smo jih v analizi identificirali glede na zastavljena raziskovalna vprašanja.

\section{Faza prehoda}

\section{Prostovoljnost namestitve}

Vsi trije mladostniki navajajo, da se za bivanje v instituciji niso odločili sami, temveč je temu botroval predlog centra za socialno delo (CSD), šole ali sodišča. M3: »Jaz nisem hotu it, ampak, potem je dala to socialka še na sodišče [...]. Pršu je un sklep al kar kol [...]. Sploh nisem mel nobene možnosti [...]. Vidu sem, ni druge opcije, zagovarjat se ne morm, postopek je, morm it, če ne, me pa bojo itak odpelal prisilno [...].« Tudi vzgojitelji izpostavljajo, da je namestitev le $v$ redkih (osamljenih) primerih prostovoljna. V4: »Mladostnik se $v$ bistvu ne zaveda, na kakšni bazi je on bil usmerjen $v$ našo enoto [...]. $V$ bistvu ves odnos z njim je tisti, ki je temelj, ki mora biti na prostovoljni bazi vzpostavljen [...] Sama namestitev pa seveda nobenemu ni povšeč [...].« Odnos, o katerem bomo spregovorili še v naslednjem poglavju, se na tem mestu znova izkaže kot ena izmed temeljnih komponent socialnopedagoškega delovanja $v$ tovrstnih institucijah. Prav tako vsi štirje vzgojitelji poudarjajo, da mladostniki namestitev največkrat doživljajo kot kazen. Podobno pravi Svetin Jakopičeva (2005; prim. Krajnčan 2006), namreč da otroci oz. mladostniki, ki vedenjsko izstopajo, zase praviloma ne iščejo pomoči, temveč jo, nasprotno, največkrat odklanjajo. Izpostaviti velja še, da kazen pri posamezniku nemalokrat izzove 
občutke lastne neuspešnosti, jezo, strah ter občutke nemoči. ${ }^{8}$ Poleg tega je $v$ laični javnosti še vedno prisotno mišljenje, da je oddaja v zavod za mladostnika kazen, za družino pa sramota (Strokovni svet Republike Slovenija za strokovno izobraževanje 2004).

Če izhajamo iz participatorne doktrine nameščanja, raziskave (Marovič 2017; Nowacki 2014; Straus in Sierwald 2008; Wolff in Hartig 2013 idr.) kažejo, da bo mladostnik, če sprejeto odločitev (namestitev v zavodsko institucijo) s svojega zornega kota doživlja kot smiselno, postopek sprejema ${ }^{9}$ (posledično namestitve) tudi sam zaznaval manj stresno, kot če je prepričan v nasprotno. Prav tako zavodsko institucijo oz. SS doživlja pozitivneje, hkrati pa so večje tudi možnosti, da bo obravnava, ki sledi, uspešna (Marovič 2019). Podobne ugotovitve navajata Straus in Sierwald (2008). Pravita, da se doživeta participacija ${ }^{10}$ pri sprejemnem postopku močno odraža skozi zavedanje posameznika o smiselnosti namestitve. Podobno tudi $V_{3}$ : »Odvisno, kako se to predstavi. Če se to predstavi, da je to ena izmed opcij v njegovem življenju, da nardi neke nove korake, al se to predstavi, da je to skazenski vodk, ker nisi bil OK, šibaš gor na Goričko ... Da se mu to predstavi kot možnost za napredek, da nekaj spremeniš pri sebi, da pri sebi nekaj dosežeš.»

\section{Ogled institucije}

Kljub temu da ogled institucije pred samo namestitvijo do nedavnega ni bil uzakonjen," v SS ves čas svojega delovanja stremijo k temu, da si, če je

${ }^{8}$ Vsi ti dejavniki lahko povzročijo številne odpore - pri starših in posamezniku, ki se ga v izvendružinsko ustanovo namešča - ter nepotrebne odkrite in/ali prikrite ovire $v$ zavodskih prizadevanjih, da bi s strokovno pomočjo pomagali posamezniku in njegovi družini (Strokovni svet Republike Slovenija za strokovno izobraževanje 2004).

${ }^{9}$ Izpostaviti velja še, da možnosti soodločanja pri sprejemnem postopku nadalje sovpadajo z občutki sprejetosti, izražanjem lastnih misli, želja ipd. Odločilno vplivajo na posameznikov psihofizični razvoj, zmanjšujejo težnjo po destruktivnem, družbeno nezaželenem vedenju, nenazadnje pa tovrstni občutki - z vidika opolnomočenja posameznika - posredno ter neposredno pomembno pripomorejo tudi k uspešnejši (re)integraciji v primarno okolje, kar pa je ne nazadnje tudi temeljni cilj zavodske vzgoje (Marovič 2017).

${ }^{10} \mathrm{Na}$ tem mestu velja izpostaviti, da slovenska zakonodaja (kljub nedavni spremembi) še vedno ne govori v prid otrokovemu/mladostnikovemu sodelovanju/soodločanju pri sprejemnem oz. namestitvenem postopku, kot je to že od leta 1991 praksa v nekaterih drugih evropskih državah (npr. Nemčiji). Podobno kot prej v nobenem izmed členov namreč eksplicitno ne vsebuje pravice do participacije otrok/mladostnikov v postopkih odločanja, temveč so, nasprotno, njihova mnenja na področju socialnovarstvenih storitev, kot ugotavljajo že Naratova, Rakarjeva in Kovačeva (2010), še vedno prepogosto spregledana.

${ }^{11} \mathrm{~S}$ sprejetjem novega ZOOMTVI (2020), ki ureja celovito obravnavo otrok/mladostnikov s ČVT/M, vključenih v mrežo zavodske vzgoje v Sloveniji (po novem poimenovano Strokovni centri), se je ta dikcija spremenila. Deveti člen omenjenega zakona namreč določa, da se strokovni delavci 
le možno, mladostnik enoto (skupaj s starši/rejniki, CSD) pred vključitvijo v izvendružinsko institucionalno obravnavo ogleda. V4: »Mladostniku damo priložnost, da najde neki uvid, vpogled $v$ tole, kako življenje pri nas poteka [...].« V2: »Pokažemo hišo, da vidi, kam prihaja, da to ni neki bau-bau [...]« Na tak način, kot navajajo, se posameznik seznani z načinom delovanja skupine, ve, kam gre, kaj pričakovati, hitreje se prilagodi, prav tako se, kot ugotavlja Krajnčan (2006), zmanjšajo strahovi in predsodki, ki so, tako Marovičeva (2019), pogosto povezani z delovanjem tovrstnih institucij.

Možnost ogleda - za katerega velja izpostaviti, da predstavlja enega izmed dejavnikov učinkovitega namestitvenega postopka - je bila dana vsem trem mladostnikom. Dva sta si institucijo pred namestitvijo ogledala, tretji omenjene možnosti ni izrabil. Kot razlog navaja negativne predhodne izkušnje (pri prvi namestitvi v podobno ustanovo) in posledično slab odnos s svojo socialno delavko. M3: »Zadnjič k sem mel ogled SS (v Kranju), je blo tko, da je rekla sSamo da vidiš, kakšne so možnosti, in se bova pol pogovarjala, kako naprej، in potem naslednjič, ko me je vidla, mi je že dala za podpisat in so me že namestili [...]. Brez tega da bi mi povedali, da me bodo [...].« Kvaliteten odnos - ki se, kot vemo, vzpostavlja na temeljih zaupanja in za katerega Krajnčan in Bajželj (2008) pravita, da je kvaliteten takrat, ko se strokovnjak in uporabnik »začutita«, tudi v procesu nameščanja mladih v izvendružinske oblike pomoči - predstavlja enega izmed odločilnih dejavnikov uspešne vključitve $v$ institucionalno obravnavo.

Če torej mladostnik ne zaupa osebi, zadolženi za nadaljnji potek njegove življenjske biografije, posledično ne zaupa $v$ sistem pomoči. Ali kot pove $V_{3}$ : "Tu se mi zdi bistveno ta en odnos, katerega ima CSD z mladostnikom, družino ... Če je to socialna delavka, s katere izhaja, da ji je mar za mladostnika, da jo skrbi, potem mladostnik tudi lažje zaupa [...]. Če je pa to samo uniformirano, te pa mladostniki, ja, dobesedno jih zavračajo [...]« Odnos, ${ }^{12}$ tako zgoraj navedena avtorja, ima torej v sebi veliko vzgojno moč. Premosti distanco,

pristojnega CSD dogovorijo za ogled strokovnega centra oz. (v našem primeru) SS, kamor se mladostnika namešča. Ker sta bila dva izmed treh mladostnikov v dotični SS nameščena še po stari zakonodaji, izhajajoč iz katere ogled institucije ni bil uzakonjen - kljub temu da ga je večina tovrstnih institucij že takrat vzpodbujala in izvajala (prim. Krajnčan in Šoln Vrbinc 2015; Marovič 2019) -, v zgornjih vrsticah izhajamo iz zakonskih podlag, ki so veljale pred spremembo zakonodaje.

${ }^{12}$ Prav tako odnos oz. (socialno)pedagoški odnos hkrati predstavlja tudi najnaravnejšo ter najpopolnejšo pot do discipline (Krajnčan in Bajželj 2008). Discipliniranje s strahom in z grožnjami, kot nadaljujeta avtorja, ni način, s katerim bi dosegli zastavljene cilje, kar izhajajoč iz ugotovitev pričujoče raziskave sovpada z zgornjimi navedbami M3. Prav tako tovrstno (zgoraj opisano) dejanje socialne delavke že v začetku zmanjša možnost, da bo obravnava, ki bo sledila, uspešna. 
pojavi se »domačnost «, s katero strokovnjak uporabnika preusmeri v smer svojega dela (Krajnčan in Bajželj 2008).

\section{Strahovi, pričakovanja, želje}

Vsi trije mladostniki navajajo, da jih je bilo strah selitve v drugo mesto/regijo. ${ }^{13}$ Prav tako so se vsi soočali s strahovi (hkrati tudi z željami), povezanimi z sprejetjem vzgojiteljev ter ostalih sostanovalcev v SS. M3: »Nisem vedu, kako se bodo obnašal do mene [...]. Kako me bodo tretiral? A bodo prijazni? A me bodo razumel?« M2: »V bistvu sem si želel, da bojo prve par dni bli bolj prijazni [...]. Da se ne bi takoj razjezli ${ }^{14}$ na mene, če bi kaj narobe nardil [...]. Upal sem, da ne bojo jezni pa da me ne bojo prvi dan meli tko, na ostro, da bom mogu vse [...]. Kot da bi že bil tam ne vem kak dolgo, to [...]. Želel sem si v bistvu samo prijazne ljudi [...]. Pa razumljive [...].«Eden izmed mladostnikov $\left(M_{1}\right)$ v povezavi z željami navaja še: »Da bi letnik nardil in, ne vem, šolo. ${ }^{15}$

Primerjava podanih odgovorov mladostnikov in vzgojiteljev pokaže, da pri prehodu posameznika iz primarne družine v izvendružinsko institucionalno obravnavo tudi vzgojitelji utemeljujejo podobne strahove kot mladostniki. V2: "Strah pred novim okoljem, novimi ljudmi ...« V3: »Pred neznanim. Ka se bo tu dogajalo? Kaj bomo od njih pričakovali? Strah jih je, da je tu kaznilnica [...]. Strah jih je, kaj si bodo drugi mislili o njih. Strah jih je povedat prijateljem [...] Strah jih je, da je to ireverzibilno, prideš pa nikol več ni poti nazaj [...].» Če izhajamo iz pričakovanj, želja in strahov, s katerimi se - v povezavi s socialnopedagoško obravnavo, ki sledi - pri namestitvi posameznika v njihovo

${ }^{13} \mathrm{Na}$ tem mestu velja opomniti, da z napotitvijo v oddaljen zavod, kot že Krajnčan (2010), ti posamezniki doživljajo dramatične spremembe. Pretrgana so dotedanja socialna razmerja (z družino, s prijatelji in pomembnimi drugimi), izgubljeni pomembni kraji, znanja in kompetence v povezavi z njimi pa postanejo nesmiselni (Wolf 1995 v Krajnčan 2012, 120). Potlačitev, izkoreninjenost ter izguba identitete so nove in dodatne težave, ki jih povzroča napotitev $v$ oddaljeni zavod (Wolf 1995 v Krajnčan 2012, 120).

${ }^{14}$ Posamezniki, ki so predhodno že bivali v podobni instituciji, pri svojih zgoraj izpostavljenih strahovih pogosto izhajajo iz lastnih negativnih izkušenj, povezanih z vedenjem oz. "zaporniškim《 odnosom vzgojiteljev do populacije s ČVT/M. V nekaterih VZ (kar lahko na podlagi večletnega dela v tovrstni instituciji potrdimo) velja namreč zmotno prepričanje določenih vzgojiteljev, da je treba otroke/mladostnike najprej »zlomiti«, da lahko potem začnemo graditi »novo«, manj destruktivno in neprimerno vedenje.

${ }^{15}$ Učna neuspešnost, kot potrjujejo številni avtorji in raziskave (Krajnčan, Miklavžin in Zorc Maver 2010; Rapuš Pavel in Kobolt 2008; Tomori 2002 idr.), predstavlja enega izmed odločilnih jezičkov na tehtnici, ki botrujejo namestitvi posameznika v izvendružinsko institucionalno ustanovo. Kot ugotavlja Flosdorf (1988 v Krajnčan, Miklavžin in Zorc Maver 2010) in kot velja še danes, je šola s svojimi fiksiranimi zahtevami po storilnosti, učenju, disciplini in socialni prilagoditvi pogosto odločilen sprožilni dejavnik za nujnost namestitve $v$ VZ. 
enoto soočajo še vzgojitelji, rezultati kažejo, da so njihovi strahovi povezani predvsem s tem, da kljub predhodno posredovani dokumentaciji ${ }^{16}$ nikoli ne vedo, kako oškodovan je mladostnik, ki se ga namešča, ter kako bo njegova namestitev vplivala na skupinsko dinamiko že nameščenih posameznikov. Eden izpostavi še, V3: »Zelo me skrbi, če pride mladostnik, keri je zelo odklonilen [...]. ${ }^{7}$ Ko zavrača ustanovo do te mere, da škodi sam sebi, ${ }^{18}$ al pa da je agresiven do drugih. ${ }^{19}{ }^{9}$ Kar se tiče pričakovanj in želja, so vsi vzgojitelji složni. Želijo si predvsem čim hitrejšo, čim uspešnejšo ter čim lažjo vključitev oz. prehod mladostnika iz primarne družine $v$ svojo enoto.

Kljub temu da vsi trije mladostniki navajajo, da so bili pred sprejemom v SS predhodno že nameščeni v podobnih izvendružinskih ustanovah (podobno

${ }^{16}$ Kot vemo, predstavlja diagnostična dokumentacija (socialnopedagoška in medicinska) predpogoj in tudi sestavni del uspešne vzgojno-izobraževalne obravnave nameščenega posameznika. Vendar se, kot kažejo ugotovitve različnih raziskav (Krajnčan in Šoln Vrbinc 2015; Marovič 2017 idr.), v praksi velikokrat zgodi, da diagnostična dokumentacija, zbrana pred prihodom otroka/mladostnika v tovrstno institucijo, ne ustreza realni sliki posameznika, kar še vedno potrjuje dobrih trideset let staro Bečajevo $(1989,16)$ tezo: »Diagnoze, kadar so sploh postavljene, niso dovolj utemeljene (skladnost anamnestičnih podatkov, ocena osebnostne strukture, sprožilne situacije in simptomatika).« Podobno na podlagi kvantitativne raziskave - ki je pokrivala celotno mrežo vzgojnih zavodov v Sloveniji - ugotavljata Krajnčan in Šoln Vrbinčeva $(2015,18)$, ki pravita, »da so nekatere informacije, ki jih dobijo, pomanjkljive, da so socialne anamneze odvisne od kakovosti in kulture truda in dejanskega stanja od CSD do CSD«. »Vzgojni zavodi navajajo tudi dejstva, da CSD namenoma prikrivajo določene informacije o otroku glede drog, nasilja, psihiatričnih izkušenj zaradi bojazni, da jih ne bodo vključili v obravnavo.« (Krajnčan in Šoln Vrbinc 2015, 20). Navedeno potrjujejo tudi ugotovitve naše raziskave, $V_{4}$ : „V bistvi bi zaj po dobrih 20 letih dela v zavodski ssceni že lehko počasi napisa register CSD-jev, za katere velja, da so poročila verodostojna, pa za katere velja, da poročila niso verodostojna [...]«

${ }^{17}$ Če posameznik že v začetku zavrača namestitev, je nemotiviran, se upira avtoriteti, je pri njem evidentna uporaba nedovoljenih substanc ali pa je morebiti opazna kakšna druga specifična problematika kompleksnih težav, iz katere izhaja, da mu v ustanovi ne morejo nuditi vseh oblik pomoči, ki bi jih potreboval, obravnava ni in ne more biti uspešna. Podroben vpogled v navedeno problematiko podajajo tudi rezultati raziskave Otroci in mladostniki s hudimi motnjami vedenja - analiza stanja (Inštitut Republike Slovenije za socialno varstvo 2011), ki se je nanašala na neustreznost namestitve v nekaterih izmed VZ v Sloveniji. Rezultati kažejo, da v enem izmed zavodov opažajo, da je $95 \%$ mladostnikov, ki so tam nameščeni, »popolnoma nemotiviranih za bivanje v zavodu in namestitev sprejemajo kot kazen« (str. 73).

${ }^{18}$ „[K]adar govorimo o notranji agresiji, samopoškodbah, se lahko v skupini pojavi trend samopoškodovanja ali pa dejanja tveganja, ko mladoletni spremljajo poizkuse suicida ali celo smrti.» (Inštitut Republike Slovenije za socialno varstvo 2011)

${ }^{19}$ Prav problem zagotavljanja varnosti vsem udeležencem vzgojno-izobraževalnega procesa predstavlja v tovrstnih ustanovah velikokrat poseben izziv, saj implicira enega od predpogojev uspešnega uresničevanja vzgojnih ciljev, ki jim moramo pri svojemu delu slediti (Marovič 2019). »Tu se srečata pravica posameznika do pomoči in šolanja ter pravica drugih otrok do varnosti - katera je pomembnejša?« (Inštitut Republike Slovenije za socialno varstvo 2011) 
V1: „Veliko mladostnikov pride k nam že iz nekih drugih namestitev (druge SS, VZ) in pri teh ni prisotnih toliko strahov. Tudi ni toliko domotožja, saj so že na nek način utečeni $v$ ta sistem [...] «), na podlagi česar so vsaj približno vedeli, kaj pričakovati, pa velja izpostaviti, da tveganje za posameznika ( $v$ smislu osebnostnih težav ter izgube nadzora nad lastnim življenjskim potekom) $z$ večkratnim premeščanjem iz ene izvendružinske institucije $v$ drugo podobno ustanovo narašča.

Kot ugotavlja Krajnčan $(2006,67)$, so ob tem še »posebej ogrožene osebnostne značilnosti, kot so obvladovanje okolja, stopnja aktivnosti in optimizma«. Strinjamo se z avtorjem, ki nadaljuje, da so ti posamezniki praviloma »igračka pristojnih in ustanov", ki načeloma nimajo pravice soodločanja o njihovi nadaljnji usodi in preseljevanju iz ustanove v ustanovo ${ }^{20}$ (str. 67). Ali kot te posameznike poimenuje eden izmed vzgojiteljev $\left(V_{3}\right)$ dotične $S S$, »second hand « mladostniki - tisti, ki izpadejo iz sistema pomoči oz. tisti, ki si jih tovrstne institucije »podajajo $z$ argumentom, da so »prerasli okvirje naše institucije».

\section{Faza sprejema/namestitve}

(Pred)priprava na sprejem

Vsi štirje vzgojitelji soglašajo, da je (pred)priprava na sprejem v veliki meri povezana z načinom, kako je mladostnik sprejet - se pravi, ali gre za urgentno ${ }^{21}$ namestitev ali za klasičen sprejem. Če gre za klasičen sprejem, v okviru (pred)priprave izpostavijo naslednje korake:

- Predhoden ogled enote oz. motiviranost mladostnika za ogled, za katerega navajajo, da: služi predvsem predstavitvi načina njihovega delovanja (tako mladostniku, ki se ga namešča, kot njegovim staršem/skrbnikom), šolanja in življenja na kmetiji; zmanjša strahove, povezane z nepoznavanjem odročne regije, in strahove, povezane z nepoznavanjem sostanovalcev; posledično pa predstavlja tudi nujen predpogoj za kasnejšo uspešno obravnavo ter integracijo v njihovo enoto. Ali kot pravi V4: »Ogled same SS pred prihodom je sigurno neke vrste

\footnotetext{
${ }^{20} \mathrm{Na}$ tem mestu velja opomniti še, da pogostost premestitev iz enega v drugi VZ - z eliminacijo posameznikov, ki veljajo za posebej problematične - večinoma služi vzpostavitvi reda v tovrstnih ustanovah, zaradi česar plačujejo otroci/mladostniki, za katere $v$ našem sistemu (kljub ustanovitvi Strokovnih centrov in sprejetju nove zakonodaje na tem področju) še vedno ni ustrezne pomoči, (pre)visoko ceno (Marovič 2019).

${ }^{21} \mathrm{O}$ urgentnih namestitvah v zavodski vzgoji govorimo takrat, ko je treba mladostnika - zaradi spolnih zlorab, fizičnega nasilja ipd. - nemudoma zaščititi oz. umakniti iz primarne družine.
} 
priprava [...] Mladostniku damo priložnost, da najde neki uvid, vpogled $v$ tole, kako življenje pri nas poteka [...]«.

- Vpogled v diagnostično dokumentacijo - za katero vsi vzgojitelji navajajo, da je velikokrat le delna - in analiza oz. preučitev le-te.

- Vzpostavitev kontakta s CSD, starši/skrbniki ${ }^{22}$ in z drugimi za mladostnika pomembnimi osebami ter institucijami.

- Sestanek (ožjega) vzgojiteljskega tima, na katerem vzgojitelji preučijo diagnostično dokumentacijo, na podlagi katere $v$ nadaljevanju socialnopedagoške obravnave snujejo nadaljnje korake pomoči. Ali, tako $V_{4}$ : »Predpriprava poteka na podlagi pregledane dokumentacije, na podlagi katere ugotovimo, s katerim že nameščenim mladostnikom bi zdaj bil ta mladostnik najbolj primeren za bivanje $v$ sobi [...]. Ali rabi svojo sobo [...]. Katere bi ble njegove močne točke, torej, kje bi se ga dalo najprej opolnomočiti [...]. V glavnem, da se že marsikaj pripraviti vnaprej [...].« Na tem sestanku ponavadi določijo še matičnega ${ }^{23}$ vzgojitelja posamezniku, ki se ga bo nameščalo, se dogovarjajo o možnostih njegovega šolanja ter določijo termin za ogled/sprejem.

- Določitev termina za ogled.

- Določitev termina za sprejem.

Kljub temu, da vzgojitelji v splošnem navajajo, da nekega posebnega protokola pri sprejemu nimajo, pa rezultati raziskave kažejo, da se protokol prvega dne vendarle zrcali v vseh podanih odgovorih. $V_{1}$ :»Mogoče to, da vedno

${ }^{22}$ Sodelovanje s starši predstavlja v izvendružinski institucionalni obravnavi, kot vemo in kot ugotavljajo številni avtorji (Žižak in Koller Trbović 2007; Mikša 2015; Dečman 2019 idr.), nepogrešljiv del triade starši - otrok - vzgojitelj (Gradišar 2015). Kot kažejo ugotovitve raziskave Stališča vzgojiteljev do aktivnega vključevanja staršev $v$ proces vzgoje v vzgojnih zavodih (Gradiša 2015), obojestransko sodelovanje med starši in vzgojitelji prav tako predstavlja temelj psihične in osebne trdnosti tako mladostnika kot staršev, hkrati pa dobro sodelovanje s starši, kot že Dečmanova (2019), posredno vpliva tudi na uspešnost obravnave nameščenih mladostnikov.

${ }^{23}$ Čeprav za uspešnost socialnopedagoške obravnave posameznika, nameščenega v SŠ, skrbijo vsi vzgojitelji skupine, pa je v vseh tovrstnih izvendružinskih institucijah matični vzgojitelj načeloma tisti, ki: je prisoten pri sprejemu v vzgojno-izobraževalno ustanovo; je zadolžen za pisanje observacij in socialnopedagoških poročil o posameznikovem funkcioniranju na vseh področjih; je udeležen na timskih sestankih in v drugih medinstitucionalnih timih; je koordinator med prenosom informacij med šolo, ki jo otrok/mladostnik obiskuje, ter zavodom, v katerem je nameščen; je vezni člen pri sodelovanju z različnimi zunanjimi institucijami; skrbi za kontinuirano sodelovanje s starši; gre s posameznikom po nakup v trgovino itd. (Marovič 2020) Ali, tako V3: »Matični vedno pride zraven, ker je to zelo pomembno [...]. Te sprejme in te tudi vozi k zdravniku [...]. Je prisoten pri namestitvi in po namestitvi tudi ostane z mladostnikom, da skupaj sobo uredita in v tem času že poteka taki spoznavni pogovor in je v bistvu tiste tri, štiri ure ta vzgojitelj posvečen samo njemu [...]. Pride samo zaradi sprejema.» 
težimo k temu, da tisti vzgojitelj, ki bo matičen temu mladostniku, pride na sprejem, da ga on sprejme, da opravijo ta začetni pogovor, da ga tudi on namesti v sobo [...]. Da se tudi že takrat vzpostavi kontakt s starši - center, s tem matičnim vzgojiteljem. « V2: »Po samem sprejemu je potem še individualni razgovor z mladostnikom, razkaže se mu hiša, okolica, prostori, oprema, vse, potem se ga pa čim bolj normalno skuša vključiti v samo skupino [...].« V3: »Ja, prvi dan je tak, centri pridejo pa starši pa mladostnik pa potem se najprej tukaj dol vsedemo, se pomenimo stvari [...].« V4: »Podpišejo se vsa soglasja, dovolilnice, dokumentacija s strani staršev [...]. Mladostnik se more soglasno strinjati s tem, da pri nas obstajajo pravila glede zlorabe alkohola, kakršnih koli intimnih odnosov [...].«

Sklenemo lahko, da protokol sprejema oz. prvega dneva temelji na odnosni komponenti oz. vzpostavitvi komunikacije med vsemi za mladostnika ključnimi referenčnimi osebami, ki so vključene $v$ potek namestitve, hkrati pa celoten postopek namestitve in prvega dne predstavlja predispozicije uspešne pomoči ter pomembno sovpada s socialnopedagoško obravnavo, ki sledi. Ali, tako V4: »Najprej poskušamo vzpostavili neki tisti enakovredni pedagoški trikotnik, kjer se potem vse sliši, vse stranke v postopku, da potem mladostnik dobi možnost, ${ }^{24}$ da postavlja svoje zahteve na neki enakovredni, enakopravni bazi [...]. To je v bistvu neka osnova, na kateri začneš potem graditi vso nadaljnjo delo z mladostnikom.«

Če se v sklopu (pred)priprave na sprejem osredotočimo še na vzgojiteljevo vlogo pri prehodu mladostnika iz primarne družine v izvendružinsko institucionalno obravnavo, tudi tukaj vsi štirje vzgojitelji - v okviru poteka sprejema in prvega dne - kot ključ do uspeha izpostavljajo vzpostavitev temeljev za nadaljnje sodelovanje med mladostnikom, starši/skrbniki, CSD ter svojo enoto.

Kot ključno komponento socialnopedagoške pomoči mladostnikom $v$ tovrstnih institucijah velja izpostaviti še enega izmed pomembnejših nepogrešljivih in velikokrat preveč zanemarjenih vidikov vzgojitelja, iz katerega bi vzgojitelji, ki v tovrstnih ustanovah delajo s posamezniki s ČVT/M, pri svojem delu nedvomno morali izhajati - V1: »Jaz tu vzgojitelja doživljam predvsem tak, da je v prvi vrsti človek. Ki razume, ne obsoja, ne sodi vsega tega [...]. Kaj? Zakaj? Na kak način se je vse to zgodlo? [...] In proba iskati maksimalno pozitivno dobro v mladostniku [...]. V osnovi, da si človek, ki razume [...].«

\footnotetext{
${ }^{24} \mathrm{Na}$ tem mestu se znova pokaže pomembnost vključevanja, soodločanja in sodelovanja posameznika pri njegovi nadaljnji življenjski biografiji: brez participatorne naravnanosti, se pravi upoštevanja, predvsem pa »lišanja« tudi glasu mladostnika ter vključevanja le-tega v celoten potek pomoči (izhajajoč iz kronološke starosti in zrelosti), obravnava, kot že izpostavljeno, ni in ne more biti uspešna.
} 


\section{Sprejem - prvi dan v instituciji}

Vedenje posameznika tekom sprejema oz. prvega dne se, kot ugotavljajo vsi vzgojitelji - razen tega, da sta pri vseh mladostnikih očitna strah in zadržanost, pri tistih, ki se jih v tovrstno ustanovo namešča prvič, tudi šok -, od posameznika do posameznika razlikuje, prav tako je le-to pogojeno z njegovimi osebnostnimi lastnostmi, lastno biografijo, s kompleksnostjo njegovih težav, razlogov, zaradi katerih se ga namešča, odnosov s starši/skrbniki ter CSD ipd.

Vzgojitelji v povezavi z doživljanjem vedenja mladostnika prvi dan izpostavljajo naslednja spoznanja: $\bigvee_{1}$ : Zelo različno [...]. Od tega, da so se že poznali in so hitro navezali kontakt, do totalnega zaprtja sam vase, v svojo sobo, zavračanja hrane, pijače [...].« V2: »Tipamo se, nej [...]« V3: »Običajno so zadržani, prestrašeni, gledajo, mencajo, ne vejo se kam dati [...] Včasih so zelo tiho pa pol čez teden dni ugotoviš, da je tak zgovoren, da sploh ne moreš verjet [...] Eni glih obratno, so prvi dan blebetavi, ker zadrego tak rešujejo, eni se v sobo zaprejo, kar tudi zjokajo se nekateri.« $V_{4}$ : „Velikokrat ${ }^{25}$ se potem poskušajo prilagoditi v tem smislu, da se nekak vlijejo notri med ostale mladostnike, to je v večini primerov [...].« Dva vzgojitelja izpostavita še (ne)merodajnost prvega dne pri (s)poznavanju in nadaljnjem poteku obravnave. V2: »Prvi dan sigurno ni neki merodajen pokazatelj mladostnika [...].« V3: »Meni je vedenje prvi dan isto kot vsak naslednji dan, saj ena lastovka še ne naznanja pomladi, tak je tudi tu."

Kar se tiče mladostnikov in njihovega doživljanja sprejema ter prvega dne $v$ ustanovi, so spomini zelo različni. Nekateri se spominjajo dejanj svojih staršev in ostalih deležnikov, ki so bili prisotni pri sprejemu, drugi so bili pozitivno presenečeni nad reakcijami vzgojiteljev in toplim sprejemom, ki so ga bili deležni - M3: »To, da sem polil vedro in pričakoval neko grajo al nek negativen odziv na to dejanje in je bla čist kontra reakcije. Vzgojiteljca je rekla: ıVsakmu se zgodi, pa kaj se zdaj sekiraš, in mi je pomagala pobrisat in je šlo naprej [...] In ko mi je pokazala sobo in mi pomagala posteljnino preoblečt. In sem bil tako in reku: ১Uauuu, zakaj mi pa to pomagate? In je rekla: 'Pa kaj, pa tuki si vsi pomagamo. «Tuki živimo skupaj in si pomagamo.« Tretji so bili navdušeni nad živalmi - M1: »So bli zajčki, ${ }^{26}$ sem bil ful navdušen;)« -, ki so del življenja na kmetiji. Vsem pa je iz spominov prvega dne skupno to, da so jih ostali, že

\footnotetext{
${ }^{25}$ V4: »So pa potem zmes tiste izjeme, ki že prvi dan poskušajo uveljaviti svoj karakter, svojo avtoriteto na neki neprimeren način, in potem hitro pride do kolizije interesov in do kakšnih koli kriznih situacij [...].«

${ }^{26}$ Terapija z živalmi predstavlja pozitivno terapevtsko sredstvo $v$ procesu socialnopedagoške obravnave mladostnikov s ČVT/M ter eno izmed metod, s katero lahko pri tovrstni populaciji pozitivno vplivamo na čustvovanje, vedenje, socialne kompetence ter odnose s soljudmi.
} 
nameščeni, mladostniki toplo sprejeli, kot tudi to, da so se vzgojitelji trudili, da bi jim sprejem čim bolj olajšali. M1: »Spodbujali so me, pač, naj se pridem dol menit, pa če kaj rabim, da naj samo rečem. « M3: "So bli prijazni, že to, ko sem pršu, da so mi npr. ponudl buhtle pa čaj pa so bli pripravljeni me spoznat, so bli potrpežljivi.«

\section{Sklepne ugotovitve}

Rezultati raziskave kažejo, da je doživljanje prehoda iz primarne družine $v$ izvendružinsko institucionalno obravnavo - tako pri mladostnikih kot njihovih vzgojiteljih - povezano s kompleksno, večdimenzionalno ter hkrati zelo subtilno dinamiko namestitvenega postopka, ki se ga ne da razumeti enoznačno. Perspektiva doživljanja prehoda je z vidika mladostnikov, vključenih $v$ raziskavo, zaznamovana predvsem $s$ strahovi, povezanimi z neznanim, novim okoljem, in nezaupanjem v tovrsten sistem pomoči kot tudi z željami po dobrih, spoštljivih ter razumevajočih odnosih z osebami, s katerimi bodo $v$ prihodnosti sobivali.

Tudi vzgojitelji kot predpogoj uspešnega prehoda izpostavijo odnos, ki predstavlja temeljno komponento celotnega namestitvenega postopka. Perspektiva doživljanja prehoda z vidika vzgojiteljev se nadalje izraža še: v motiviranosti mladostnika (za ogled/nadaljnjo obravnavo); želji po pridobitvi popolne diagnostične dokumentacije; vzpostavitvi temeljev korektnega odnosa (s CSD, starši/skrbniki in z drugimi za mladostnika pomembnimi osebami ter institucijami), za katerega navajajo, da predstavlja ključ do uspeha pri nadaljnjem sodelovanju med mladostnikom ter njihovo enoto. Predvsem pa si vsi vzgojitelji želijo čim hitrejšo, uspešnejšo ter čim lažjo vključitev oz. prehod mladostnika iz primarne družine v svojo enoto.

Čeprav zaradi majhnosti vzorca pridobljenih rezultatov ne moremo posploševati na celotno zavodsko populacijo, pa lahko (tudi izhajajoč iz več kot desetletnega dela $v$ procesu prehoda/namestitve $v$ tovrstne institucije) sklenemo, da se odločilni dejavniki, ki prispevajo k uspešnosti prehoda in nadaljnji socialnopedagoški obravnavi, zrcalijo na kontinuumu: (1) participatorne doktrine nameščanja, ki zajema možnost predhodnega ogleda institucije in za katerega velja ponovno izpostaviti, da predstavlja enega izmed temeljnih predpogojev učinkovitega namestitvenega postopka - na tak način se zmanjšajo prenekateri strahovi, povezani z nepoznavanjem kraja, sostanovalcev in vzgojiteljev, ki v času veljave ukrepa oddaje predstavljajo »novo (zakonsko določeno)« družinsko okolje; (2) doživljanja zaznavanja sprejema in prvega dne $v$ instituciji ( $\mathrm{z}$ vidika mladostnika), ki pa nadalje sovpada $\mathrm{z}$ (3) odnosno komponento, ki se kot »rdeča nit« zrcali skozi fazo prehoda in fazo 
sprejema/namestitve ter predstavlja predpogoj učinkovitemu socialnopedagoškemu delu v vseh - ne samo izvendružinskih - vzgojno-izobraževalnih ustanovah.

Izhajajoč iz navedenega in ob upoštevanju pomanjkanja raziskav na tem področju pa je treba znova poudariti, da bi v prihodnosti tudi temu raziskovalnemu polju veljalo nameniti več prostora. Predvsem zaradi vedenja, da se (pre)pogosto zanemarjen vidik doživljanja mladostnikov ob prehodu v zavodsko institucijo odraža v neizogibni spremembi že tako nezavidljivih življenjskih okoliščin, ločenosti od družine ipd., kar lahko dodatno ogroža posameznikov razvoj na vseh področjih njegovega psihosocialnega funkcioniranja.

\section{Literatura}

Bečaj, J. 1989. »Oddaja otrok in mladostnikov v vzgojne zavode: kriteriji za oddajo v vzgojni zavod.«Ptički brez gnezda 13 (27): 7-29.

Dečman, M. 2019. "Svetovalno in terapevtsko delo z družinami.« V Uvajanje sprememb pri podpori mladim s čustvenimi in vedenjskimi težavami, ur. I. Kreft Toman, 131-151. Ljubljana: Mladinski dom Jarše.

Družinski zakonik (DZ). 2017. Uradni list Republike Slovenije, št. 15. https://www .uradni-list.si/1/objava.jsp?sop=2017-01-0729.

Flosdorf, P., ur. 1988. Theorie und Praxis stationärer Erziehungshilfe. Freiuburg: Lambertus.

Gradišar, M. 2015. »Stališča vzgojiteljev do aktivnega vključevanja staršev v proces vzgoje in izobraževanja v vzgojnih zavodih. « V Moči, izzivi, vizije vzgojnih zavodov, ur. A. Kobolt, 171-188. Ljubljana: Pedagoška fakulteta.

Grunwald, K., in H. Thiersch. 2008. »Koncept socialne pedagogike, usmerjene v življenjski svet - uvodna opažanja.« V Socialna pedagogika - med teorijo in prakso, ur. M. Krajnčan, D. Zorc Maver in B. Bajželj, str. 7-26. Ljubljana: Pedagoška fakulteta.

Inštitut Republike Slovenije za socialno varstvo. 2011. Otroci in mladostniki s hudimi motnjami vedenja - analiza stanja. Ljubljana: Inštitut Republike Slovenije za socialno varstvo.

Kazenski zakonik (KZ-1-UPB2). 2012. Uradni list Republike Slovenije, št. 50. https:// www.uradni-list.si/1/objava.jsp?sop $=2012-01-2065$.

Kobolt, A. 2018. »Od posebnih do univerzalnih potreb in nazaj ali raziskovalni in izkustveni vpogledi v udejanjanje načelnega v trenutni pedagoški praksi.» Socialna pedagogika 22 (3-4): 165-174.

Kobolt, A., A. Žižak in N. Zrim Martinjak. 2019. »Oris procesov in izidov deinstitucionalizacije skrbi za ranljive skupine - v tujini in doma.« V Uvajanje sprememb pri podpori mladih s čustvenimi in vedenjskimi težavami, ur. I. Kreft Toman, 11-40. Ljubljana: Mladinski dom Jarše. 
Krajnčan, M. 2006. Na pragu novega doma: oddaja otrok v vzgojni zavod. Ljubljana: Pedagoška fakulteta.

- 2010. „Otroci in mladostniki v vzgojnih zavodih, stanovanjskih skupinah in mladinskih domovih. "V Zdravje mladostnikov s čustvenimi in vedenjskimi težavami, ur. M. Krajnčan in P. Miklavžin, 34-55. Ljubljana: Ministrstvo za zdravje.

—. 2012. »Dezinstitucionalizacija na področju vzgojnih zavodov.« Časopis za kritiko znanosti 39 (250): 116-127.

_. 2019. »Strokovni center in proces deinstitucionalizacije.«V Kam zotroki? Strokovni center Maribor - celostna obravnava otrok s čustvenimi in vedenjskimi motnjami v vzgojnih zavodih, ur. M. Krajnčan, 10-26. Maribor: Strokovni center.

Krajnčan, M., in B. Bajželj. 2008. »Odnos - osnova za socialnopedagoško delo.« V Socialna pedagogika med teorijo in prakso, ur. M. Krajnčan, D. Zorc Maver in B. Bajželj, 55-70. Ljubljana: Pedagoška fakulteta.

Krajnčan, M., in P. Šoln Vrbinc. 2015. »Med preteklostjo in prihodnostjo zavodske vzgoje.«V Moči, izzivi, vizije vzgojnih zavodov, ur. A. Kobolt, 11-33. Ljubljana: Pedagoška fakulteta.

Krajnčan, M., P. Miklavžin in D. Zorc Maver. 2010. »Oris zdravstvene problematike (namen raziskovanja). "V Zdravje mladostnikov s čustvenimi in vedenjskimi težavami, ur. M. Krajnčan in P. Miklavžin, 57-99. Ljubljana: Ministrstvo za zdravje.

Marovič, M. 2017. »Participacija otroka/mladostnika v vzgojnih zavodih.« Doktorska disertacija, Univerza na Primorskem.

—. 2019. »Nameščanje in diskurz o (ne)ustreznosti vzgojne pomoči otro$\mathrm{kom} /$ mladostnikom s čustvenimi in vedenjskimi težavami in ali motnjami v vzgojnih zavodih." V Večdimenzionalnost socialnopedagoških diskurzov, ur. M. Marovič in A. Sinjur, 129-148. Koper: Založba Univerze na Primorskem.

- 2020. »Medinstitucionalna/multidisciplinarna obravnava mladostnika, nameščenega v vzgojnem zavodu. « V Medpredmetno povezovanje: pot do uresničevanja vzgojno-izobraževalnih ciljev, ur. M. Volk, T. Štemberger, A. Sila in N. Kovač, 215-230. Koper: Založba Univerze na Primorskem.

Martinjak, N. 2017. »Razlogi za današnje delovanje vzgojnih zavodov v Sloveniji.« Socialna pedagogika 21 (1-2): 73-94.

Mikša, L. 2015. »Sodelovanje s starši otrok v vzgojnih ustanovah. "V Moči, izzivi, vizije vzgojnih zavodov, ur. A. Kobolt, 189-209. Ljubljana: Pedagoška fakulteta.

Ministrstvo za izobraževanje, znanost in šport. B. I. »Priloga k Vzgojnemu programu: zavodi za vzgojo in izobraževanje.« https://www.gov.si/assets/ ministrstva/MIZS/Dokumenti/Izobrazevanje-otrok-s-posebnimi -potrebami/SS/Drugi-programi/40ofc6dfa/Priloga_vzgojni_program.pdf. 
Narat, T., T. Rakar in N. Kovač. 2010. Participacija otrok v postopkih odločanja: končno poročilo. Ljubljana: Inštitut Republike Slovenije za socialno varstvo.

National Association of Social Workers in Oxford University Press. 2013. Encyclopedia of Social Work. 2013. New York: Oxford University Press.

Nowacki, K. 2014. Die Neuafnahme in der stationären Heimerziehung. Freiburg: Lambertus.

Rapuš Pavel, J., in A. Kobolt. 2008. »Alkoholizem v družini in doživljanja mladostnic, ki bivajo v vzgojnem zavodu. $V$ Socialna pedagogika med teorijo in prakso, ur. M. Kranjčan, D. Zorc Maver in B. Bajželj, 97-120. Ljubljana: Pedagoška fakulteta.

Rosenthal, E. 2017. »A Mandate to End Placement of Children in Institutions and Orfanages: The Duty of Governments and Doners to Prevent Segregation and Torture." V Protecting Children Against Torture in Detention: Global Solutions for a Global Problem, ur. J. Mendez, 303-352. American University, Washington College of Law in Center for Human Rights \& Humanitarian Law.

Skalar, V. 1998. »Vzgojne ustanove na prehodu v postindustrijsko družbo.« Socialna pedagogika 2 (2): 5-17.

Straus, F., in W. Sierwald. 2008. "Gelingende Beteiligung im Heimalltag aus der Sicht von Jugendlichen.«http://www.diebeteiligung.de/pdf/spi2009_2 _studie_gelingende_beteiligung.pdf.

Strokovni svet Republike Slovenija za strokovno izobraževanje. 2004. »Vzgojni program.«http://www.mizs.gov.si/fileadmin/mizs.gov.si/pageuploads/ podrocje/posebne_potrebe/programi/Vzgojni_program.pdf.

Svetin Jakopič, S. 2005. »Obravnava otrok in mladostnikov z vedenjskimi motnjami na centru za socialno delo: pomoč ali prisila. "Socialna pedagogika 9 (4): 391-422.

Tomori, M. 2002. »Šolska neuspešnost kot dejavnik tveganja za celostni osebnostni razvoj.« V Šolska neuspešnost med otroki in mladostniki: vzroki - posledice - preprečevanje, ur. K. Bergant in K. Musek Lešnik, 16-18. Ljubljana: Inštitut za psihologijo osebnosti.

Wolff, K. 1995. »Wohin hat uns die Heimerziehung gebracht?« V Entwicklungen in der Heimerziehung, ur. K. Wolff, 92-103. Munster: Votum Verlag.

Wolff, M., in S. Hartig. 2013. Gelingende Beteiligung in der Heimerziehung: Ein Werkbuch für Jugendliche und ihre Betreuerinnen. Weinheim in Basel: Beltz Juventa.

Zakon o nepravdnem postopku (ZNP-1). 2019. Uradni list Republike Slovenije, št. 16. https://www.uradni-list.si/1/objava.jsp?sop=2019-01-0613.

Zakon o obravnavi otrok in mladostnikov s čustvenimi in vedenjskimi težavami in motnjami v vzgoji in izobraževanju (ZOOMTVI). 2020. Uradni list Republike Slovenije, št. 200. https://www.uradni-list.si/1/objava.jsp?sop=202001-3628. 
Zavod Republike Slovenije za šolstvo. 2015. Kriteriji za opredelitev vrste in stopnje primanjkljajev, ovir oz. motenj otrok s posebnimi potrebami. Ur. N. VovkOrnik. Ljubljana: Zavod Republike Slovenije za šolstvo.

Žižak, A., in N. Koller Trbović. 2007. „Temna stran družinskega življenja v doživljanju otrok in mladostnikov.« Socialna pedagogika 11 (2): 147-170.

\section{New Family: The Transition of the Adolescent from Primary Family to Extra-family Institutional Treatment}

The article deals with the views of adolescents and educators at the transition from primary family to extra-family institutional treatment, considering two different perspectives - the perspective of adolescents and their educators. The qualitative survey, which included seven participants (three adolescents and four educators) with transition experience, focuses mainly on the transition phase and the reception/placement phase. The results of the research show that the experience of transition from primary family to extra-family institutional treatment - both for adolescents and their educators - is associated with complex, multidimensional, and at the same time very subtle dynamics of the placement process, which cannot be understood unambiguously.

Keywords: transition, placement, extra-family institutional treatment, adolescents with emotional and behavioural difficulties and/or disorders, sociopedagogical treatment 